\title{
Myocardial Protective Effects of Nicorandil During Percutaneous Coronary Intervention in Patients With Unstable Angina
}

\author{
Ju Han Kim, MD; Myung Ho Jeong, MD; Kyung Ho Yun, MD; Kye Hun Kim, MD; \\ Dong Koo Kang, MD; Seo Na Hong, MD; Sang Yup Lim, MD; Sang Hyun Lee, MD; \\ Yun Sang Lee, MD; Young Joon Hong, MD; Hyung Wook Park, MD; \\ Weon Kim, MD; Young Keun Ahn, MD; Jeong Gwang Cho, MD; \\ Jong Chun Park, MD; Jung Chaee Kang, MD
}

\begin{abstract}
Background The purpose of the study was to prospectively evaluate the protective effect of nicorandil during percutaneous coronary intervention (PCI) in patients with unstable angina (UAP).

Methods and Results Two hundred patients (61 \pm 10 year-old, male 143) diagnosed with UAP at an emergency medical center were randomly assigned to 2 groups: intravenous isosorbide dinitrate, Group I $(n=100)$, or intravenous nicorandil, Group II $(\mathrm{n}=100)$. PCI was performed $12-48 \mathrm{~h}$ after infusion of each agent. Serum concentrations of creatine kinase-MB (CK-MB), cardiac troponin T (cTnT), and I (cTnI) were measured before and 6, 12, 24h after PCI. Patients with non-coronary chest pain, requiring emergency coronary angiogram, temporary pacemaker or glycoprotein IIb/IIIa receptor blocker were excluded. PCI was successfully performed in 96 patients (Group $\mathrm{I}=54,61.7 \pm 8.2$ years, 32 males; Group $I=42,60.4 \pm 11.7$ years, 27 males). No significant differences in clinical or coronary angiographic characteristics were observed between the 2 groups. The concentration of CK-MB was elevated in 9 patients (17\%) of Group I and 6 (14\%) of Group II, cTnT in 16 (30\%), 6 (14\%) and cTnI in 25 (46\%), 9 (21\%) after PCI. Elevation of any troponin was less frequent in Group II [28/54 $(52 \%)$ vs $10 / 42(24 \%)$ patients, $\mathrm{p}=0.01]$. Major adverse coronary events during the 6-month clinical follow-up occurred in 9 (17\%) of Group I and 5 patients of Group II $(12 \%, \mathrm{p}=\mathrm{NS})$. Follow-up echocardiography revealed lower left ventricular ejection fraction in Group I than in Group II $(65.4 \pm 7.2 \%$ vs $71.0 \pm 6.7 \%, \mathrm{p}=0.03)$.

Conclusion Nicorandil has a myocardial protective effect during PCI in patients with UAP. (Circ J 2005; 69: $306-310$ )
\end{abstract}

Key Words: Angioplasty; Nicorandil; Percutaneous coronary intervention; Unstable angina

$\mathbf{M}$ yocardial injury commonly occurs during percutaneous coronary intervention (PCI) and can be easily monitored by measuring myocardial enzymes! ${ }^{1-4}$ Nicorandil is the opener of the adenosine triphospate (ATP)-sensitive $\mathrm{K}^{+}$channel and is known to have an antiarrhythmic effect, through shortening of the action potential, and myocardial protective functions, such as the reduction of the resistance of micro-coronary artery flow by relaxing the smooth muscles of blood vessel and preconditioning $5-8$ Investigating the myocardial protective effect of nicorandil, the IONA study (Impact of Nicorandil in Angina), a large-scale research on stable angina, reported that oral administration of nicorandil reduced death from coronary artery disease and unexpected hospitalization for non-fatal myocardial infarction or chest pains? There have been several studies evaluating the myocardial

(Received July 26, 2004; revised manuscript received December 6, 2004; accepted December 9, 2004)

The Heart Center of Chonnam National University Hospital, Chonnam National University Research Institute of Medical Sciences, Gwnagju, Korea

Mailing address: Myung Ho Jeong, MD, PhD, FACC, FESC, FSCAI, Professor, Chief of Cardiovascular Medicine, Director of Cardiac Catheterization Laboratory, The Heart Center of Chonnam National University Hospital, 8 Hakdong, Dongku, Gwangju 501-757, Korea. E-mail: myungho@chollian.net protective effect of nicorandil for unstable angina (UAP) or acute myocardial infarction patients, but no large-scale research has been carried out yet ${ }^{10-12}$

The purpose of this study was to prospectively examine the myocardial protective effect of nicorandil by evaluating the myocardial enzymes of the patients with UAP who underwent successful PCI 12-48h after the injection of nicorandil.

\section{Methods}

Subjects

The subjects were 200 patients who visited the Emergency Medical Center of Chonnam National University Hospital for chest pain during the period March to December 2002 and who were clinically diagnosed as UAP, but definitely ruled out from having myocardial infarction. This study excluded those who had a history of myocardial infarction within the past 3 months, valvular heart disease or a myocardial disease, musculoskeletal disease, bundle-branch block or atrioventricular block, pacemaker, uncontrollable diabetes or oral ulcer. Patients with systolic blood pressure below $100 \mathrm{mmHg}$, or who were currently taking sulfonylurea or had been for more than 5 years in the past were also excluded. 


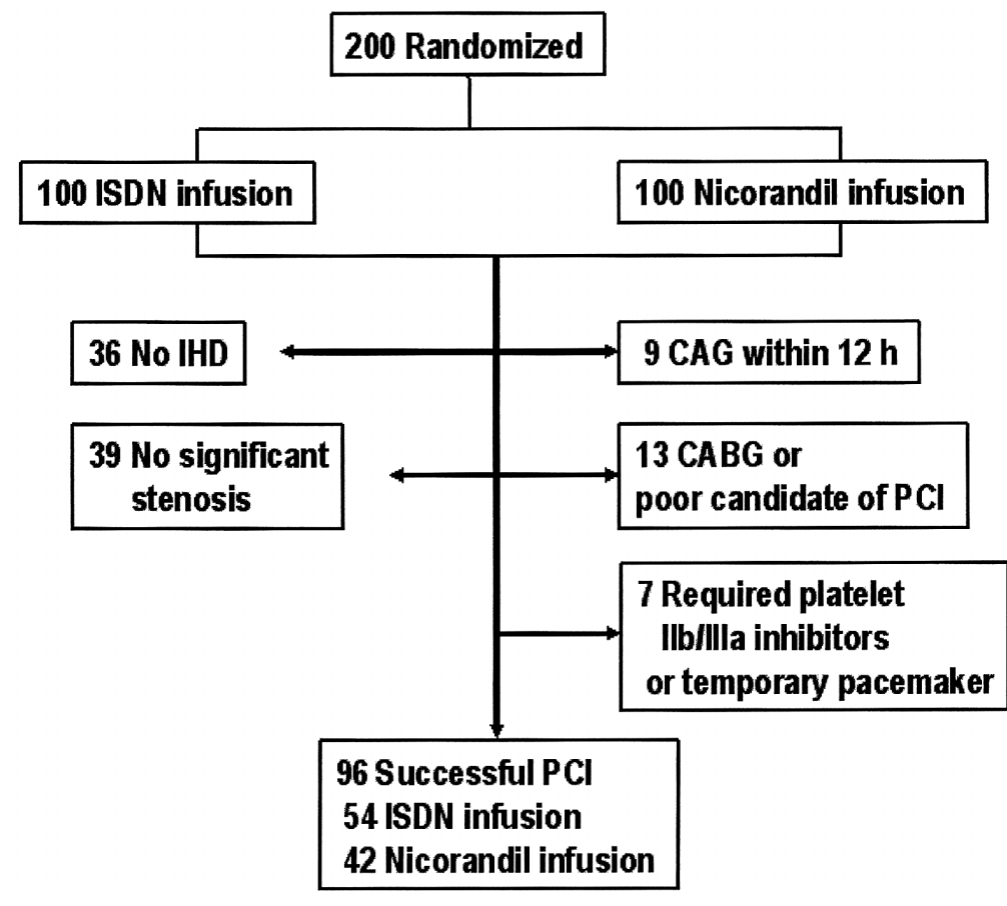

Fig 1. Schematic diagram of the study patients ISDN, isosorbide dinitrate; IHD, ischemic heart disease; CAG, coronary angiogram; PCI, percutaneous coronary intervention; $\mathrm{CABG}$, coronary artery bypass graft.

\section{Study Groups and Treatment}

All patients were treated according to the diagnosis of UAP, and they were randomly divided into 2 groups in order of admission to the hospital. Patients in Group I $(n=100)$ were treated with isosorbide dinitrate injection and those in Group II $(n=100)$ with nicorandil. The injection of isosorbide dinitrate began at $2 \mathrm{mg} / \mathrm{h}$ and was gradually increased to $4 \mathrm{mg} / \mathrm{h}$, with a further increase up to $8 \mathrm{mg} / \mathrm{h}$ or decrease depending on the patients' symptoms. The initial nicorandil treatment was a $4 \mathrm{mg}$ injection, and then infusion at a rate of $4 \mathrm{mg} / \mathrm{h}$, up to $6 \mathrm{mg} / \mathrm{h}$ or less depending on symptoms. Both treatments were given for $12-48 \mathrm{~h}$ before PCI and for $48 \mathrm{~h}$ after PCI, then replaced with oral medication of $80-160 \mathrm{mg} /$ day ISDN in group I and $10-15 \mathrm{mg} /$ day nicorandil in group II for the next 6 months. Patients who required urgent PCI within $12 \mathrm{~h}$ of the treatment initiation were excluded from the analysis (Fig 1).

\section{Coronary Angiography and PCI}

Coronary angiography was mainly carried out via the radial artery or femoral artery using a 5 or 6 French coronary artery introducer (Judkins or Amplatz). Lesions were classified according to the American College of Cardiology/American Heart Association (ACC/AHA), ${ }^{13}$ and coronary artery blood flow was evaluated as Thrombolysis In Myocardial Infarction (TIMI) flow! ${ }^{14}$

Depending on the angiography results and the patient's condition, treatment was PCI, coronary artery bypass graft $(\mathrm{CABG})$ or medication. Patients allocated to PCI were given aspirin and ticlopidine or clopidogrel before the procedure, and PCI was performed through either the radial or femoral artery using a 6-8 French introducer (Judkins or Amplatz). Before starting the procedure, 7,500-10,000 units of heparin were given iv and the activated clotting time was maintained at $>300$ s. Once the guide wire passed through the culprit lesion, balloon dilatation or a stent placement was performed using a Phillips H5000 or Allura digital cardiac imaging system. The treatment was regarded as successful when the luminal diameter of the target artery increased by at least by $50 \%$, residual stenosis was less than $30 \%$ and TIMI flow was grade 3 . If platelet glycoprotein IIb/IIIa inhibitor was used before PCI, or a temporary pacemaker was inserted, the case was excluded from analysis.

\section{Cardiac Enzymes}

In 96 successful PCI patients, blood was collected just before PCI and 6, 12 and $24 \mathrm{~h}$ from PCI, for measurement of the concentrations of creatine kinase (CK), CK-MB, cardiac troponins $\mathrm{T}$ (cTnT) and I (cTnI). CK and CK-MB was measured by immune inhibition method (Synchron CX9, Beckman Coulter, USA), cTnT and cTnI by immunoassay (Elecys 1020, Boehringer Mannheim Diagnostics, Germany and Opus, Dade Behring Inc, USA, respectively). The normal reference values for CK-MB, cTnT and cTnI were $<8 \mathrm{mg} / \mathrm{dl}, 0.05 \mathrm{ng} / \mathrm{ml}$, and $0.01 \mathrm{ng} / \mathrm{ml}$, respectively. In each test, the value just before PCI was compared with the highest of those obtained after PCI to examine the myocardial protective effect of each drug. Elevation of CK-MB was defined as maximal value of CK-MB $>16 \mathrm{mg} / \mathrm{dl}$ and elevated more than $5 \%$ of the value before PCI. Elevation of cTnT was defined as maximal value $>0.2 \mathrm{ng} / \mathrm{ml}$ and elevated more than $>0.1 \mathrm{ng} / \mathrm{ml}$ before PCI. Elevation of cTnI was defined as maximal value $>0.1 \mathrm{ng} / \mathrm{ml}$ and elevated more than $>0.05 \mathrm{ng} / \mathrm{ml}$ before PCI.

\section{Clinical Follow-up}

Throughout the 6-month follow-up, the 2 groups were compared in terms of major adverse cardiac events (MACE), such as cardiac death, myocardial infarction accompanied by increased CK-MB, or revascularization such as PCI or CABG. Echocardiography was carried out on both the admission day and at the 6th month, by different physicians unaware of which group the patients were from. The left ventricular ejection fraction (LVEF) was measured by the area-length method on both the admission day and at the $6^{\text {th }}$ month, and the results of both examinations were compared between the 2 groups. 
Table 1 Clinical and Angiographic Characteristics of the Study Groups

\begin{tabular}{|c|c|c|c|}
\hline & $\begin{array}{c}\text { Group I } \\
(n=54)\end{array}$ & $\begin{array}{c}\text { Group II } \\
(n=42)\end{array}$ & $p$ value \\
\hline Age (years) & $61.7 \pm 8.2$ & $60.4 \pm 11.7$ & 0.54 \\
\hline Male $(\%)$ & $32(59)$ & $27(64)$ & 0.68 \\
\hline \multicolumn{4}{|l|}{ Risk factor (\%) } \\
\hline Smoking & $25(46)$ & $119(45)$ & 0.59 \\
\hline Hypertension & $32(59)$ & $29(69)$ & 0.60 \\
\hline Diabetes mellitus & $6(11)$ & $5(12)$ & 0.62 \\
\hline Family history & $2(4)$ & $1(2)$ & 0.52 \\
\hline Hyperlipidemia & $21(39)$ & $17(41)$ & 0.64 \\
\hline \multicolumn{4}{|c|}{ Angiographic findings (\%) } \\
\hline 1-vessel disease & $32(59)$ & $27(64)$ & \multirow{3}{*}{0.59} \\
\hline 2-vessel disease & $15(28)$ & $8(19)$ & \\
\hline 3-vessel disease & $7(13)$ & $7(17)$ & \\
\hline \multicolumn{4}{|l|}{ Target artery (\%) } \\
\hline$L A D$ & $31(57)$ & $23(55)$ & \multirow{3}{*}{0.61} \\
\hline$L C X$ & $13(24)$ & $10(24)$ & \\
\hline$R C A$ & $10(19)$ & $19(21)$ & \\
\hline \multicolumn{4}{|l|}{ АCС/AHА Type (\%) } \\
\hline$A$ & $1(2)$ & $0(0)$ & \multirow{4}{*}{0.07} \\
\hline$B_{1}$ & $34(63)$ & $20(48)$ & \\
\hline$B_{2}$ & $7(13)$ & $15(36)$ & \\
\hline$C$ & $12(22)$ & $7(17)$ & \\
\hline \multicolumn{4}{|l|}{ TIMI flow (\%) } \\
\hline 0 & $5(9)$ & $1(2)$ & \multirow{4}{*}{0.41} \\
\hline$I$ & $5(9)$ & $2(5)$ & \\
\hline II & $11(20)$ & $11(26)$ & \\
\hline III & $33(61)$ & $28(67)$ & \\
\hline \multicolumn{4}{|l|}{ Procedure (\%) } \\
\hline Ballooning & $7(13)$ & $11(26)$ & \multirow{2}{*}{0.12} \\
\hline Stenting & $47(87)$ & $31(74)$ & \\
\hline \multicolumn{4}{|l|}{ Intervention (\%) } \\
\hline Single vessel & $44(82)$ & $35(83)$ & \multirow{2}{*}{0.82} \\
\hline Multiple vessel & $10(18)$ & $7(17)$ & \\
\hline
\end{tabular}

$L A D$, left anterior descending artery; LCX, left circumflex artery; RCA, right coronary artery; ACC/AHA, American College of Cardiology/American Heart Association; TIMI, Thrombolysis In Myocardial Infarction.

Table 2 Incidence of Elevated Cardiac Enzymes During Percutaneous Coronary Intervention

\begin{tabular}{lrrr}
\hline \hline & $\begin{array}{c}\text { Group I } \\
(n=54)\end{array}$ & $\begin{array}{c}\text { Group II } \\
(n=42)\end{array}$ & p value \\
\hline$C K-M B$ & $9(17 \%)$ & $6(14 \%)$ & 0.67 \\
Troponin T & $16(30 \%)$ & $6(14 \%)$ & 0.06 \\
Troponin I & $25(46 \%)$ & $9(21 \%)$ & 0.03 \\
Elevated troponin & $28(52 \%)$ & $10(24 \%)$ & 0.01 \\
\hline
\end{tabular}

$C K-M B$, creatine kinase isoenzyme-MB.

\section{Statistical Analysis}

All measurements are represented as mean value \pm standard deviation. Student's t-test, ANOVA and Fisher's exact test were conducted using SPSS (Chicago, IL, USA), and statistical significance was admitted when $\mathrm{p}<0.05$.

\section{Results}

Of the 200 patients, 36 were excluded because their chest pain was caused by other than ischemic heart disease, 9 required urgent coronary angiography within $12 \mathrm{~h}$ of drug administration because their chest pain was uncontrollable, and another 155 underwent elective coronary angiography between 12 and $48 \mathrm{~h}$ of drug administration. No significant coronary stenosis was observed in 39 of those 155 cases, and $\mathrm{CABG}$ or medical treatment was carried out in 13 cases because PCI was not indicated. As a result, 103 patients underwent PCI and 6 needed $\mathrm{IIb} / \mathrm{III}$ inhibitor as planned or for rescue because of no-reflow or side branch occlusion and 1 case needed a temporary pacemaker for rescue because of complete heart block. PCI was successful in 96 cases: 54 in Group I and 42 in Group II (Fig 1).

The comparative results for the 96 cases of successful PCI only are as follows. There were 25 smokers $(46 \%)$ in Group I and 19 (45\%) in Group II, there were $32(59 \%)$ and $29(69 \%)$ patients with hypertension, respectively, $6(11 \%)$ and $5(12 \%)$ with diabetes, $2(4 \%)$ and $1(2 \%)$ with a family history of ischemic heart disease, and 21 (39\%) and 17 $(41 \%)$ with hyperlipemia. There was no significant difference between the group for coronary risk factors.

According to the coronary angiography results, there were 32 cases of single-vessel disease (59\%), 15 cases of 2vessel disease (28\%) and 7 cases of 3-vessel disease (13\%) in Group I and $27(64 \%), 8(19 \%)$ and $7(17 \%)$, respectively, in Group II. No significant difference was observed between the groups. The target lesion was in the left anterior descending artery in $31(57 \%)$ and $23(55 \%)$ cases in Group I and Group II, respectively, in the left circumflex artery in $13(24 \%)$ and $10(24 \%)$ and in the right coronary artery in $10(19 \%)$ and $9(21 \%)$. No significant difference was observed between the groups. As for the type of lesion, there were 2 cases of Type A was (2\%), 34 of Type B1 (63\%), 7 of Type $\mathrm{B}_{2}(13 \%)$ and 12 of Type C (22\%) in Group I, and 0 (0\%), 20 (48\%), $15(36 \%)$ and $7(17 \%)$, respectively, in Group II. As for TIMI flow, there were 5 cases of TIMI 0 was (9\%), 5 of TIMI I (9\%), 11 of TIMI II $(20 \%)$ and 33 of TIMI III (61\%) in Group I, and $1(2 \%), 2$ (5\%), 11 (26\%) and 28 (67\%), respectively, in Group II. No significant difference was observed between the groups (Table 1).

As for PCI, 7 cases (13\%) had balloon dilatation only and $47(87 \%)$ had balloon dilatation and then stenting in Group I, and there were 11 cases (26\%) and 31 (74\%), respectively, in Group II. Multivessel PCI was performed in 10 cases (18\%) in Group I and 7 cases (17\%) in Group II, and no significant difference was observed between the groups.

CK-MB, cTnT and cTnI concentrations in Group I were $10.7 \pm 6.3 \mathrm{mg} / \mathrm{dl}, \quad 0.02 \pm 0.05 \mathrm{ng} / \mathrm{ml}$ and $0.31 \pm 0.68 \mathrm{ng} / \mathrm{ml}$, respectively, and $9.6 \pm 4.9 \mathrm{mg} / \mathrm{dl}, 0.04 \pm 0.10 \mathrm{ng} / \mathrm{ml}$ and $0.35 \pm 1.38 \mathrm{ng} / \mathrm{ml}$ in Group II. Maximum concentrations after PCI were $9.1 \pm 7.0 \mathrm{mg} / \mathrm{dl}, 0.03 \pm 0.05 \mathrm{ng} / \mathrm{ml}$ and I $0.69 \pm$ $1.24 \mathrm{ng} / \mathrm{ml}$, respectively, in Group I, and $8.5 \pm 6.2 \mathrm{mg} / \mathrm{dl}$, $0.03 \pm 0.06 \mathrm{ng} / \mathrm{ml}$ and $0.36 \pm 0.68 \mathrm{ng} / \mathrm{ml}$ in Group II. Delta values defined as maximum value minus the value before PCI, were $1.2 \pm 3.5 \mathrm{mg} / \mathrm{dl}, 0.01 \pm 0.02 \mathrm{ng} / \mathrm{ml}$ and $0.33 \pm$ $1.32 \mathrm{ng} / \mathrm{ml}$, respectively, in Group I, and $1.1 \pm 2.6 \mathrm{mg} / \mathrm{dl}$, $0.01 \pm 0.01 \mathrm{ng} / \mathrm{ml}$ and $0.14 \pm 0.39 \mathrm{ng} / \mathrm{ml}$ in Group II. After PCI, CK-MB was increased in 9 cases (17\%) in Group I and 6 (14\%) in Group II, cTnT was increased in 16 cases $(30 \%)$ in Group I and $6(14 \%)$ in Group II, and cTnI was increased in 25 cases (46\%) in Group I and $9(21 \%)$ in group II, and for all troponins, the concentration was increased in 28 cases (52\%) in Group I and 10 (24\%) in Group II. The incidence of increased enzyme concentrations was significantly lower in Group II than in Group I $(\mathrm{p}=0.01)$.

During the 6-month follow-up period, there were 2 cases (4\%) of myocardial infarction in Group I and $1(2 \%)$ in Group II, and $1(17 \%)$ and $4(10 \%)$ of reperfusion such as PCI or CABG. Nine cases (17\%) of MACE occurred in Group I and 5 (12\%) in Group II, but without significant 
difference between the 2 groups $(\mathrm{p}=0.57)$.

The LVEF measured by echocardiography was $66.5 \pm$ $7.8 \%$ in Group I and $64.7 \pm 9.0 \%$ in Group II on admission and no significant difference was observed between the 2 groups, but 6 months later it was $65.4 \pm 7.2 \%$ in Group I and $71.0 \pm 6.7 \%$ in Group II, which was significantly higher than Group I ( $\mathrm{p}=0.03$, Fig 2).

\section{Discussion}

Increased myocardial troponin concentration is commonly observed during PCI in patients with coronary artery disease and is known to be caused by damage to the myocardial cells during PCI. However, the myocardial troponin concentration has not been used properly to monitor the damage to myocardial cells after successful PCI4,15-18 Myocardial troponin is a protein controlling myocardial contraction and is not detected in the blood under normal conditions. Because it is cardiac specific, it can be used as an indicator of myocardial damage and is more sensitive and specific to myocardial cell damage than CK-MB!9-20 The authors have previously reported that the release of myocardial troponin after PCI is common in patients with successful PCI, particularly TnI, which is a sensitive indicator of minor myocardial damage 4

It has been found that the higher the concentration of myocardial troponin on admission for acute coronary artery syndrome the higher the incidence of myocardial infarction and death, so the myocardial troponin concentration is used in the evaluation of acute coronary artery syndrome patients for establishing the treatment strategies and evaluating prognosis $2^{23}-25$

Nicorandil is a compound of a nicotinamide derivative and nitrate moiety, which works like a nitrate drugs and at the same time opens ATP-sensitive $\mathrm{K}^{+}$channels. similar to the nitrate drugs it increases blood flow in the coronary artery and decreases both preload and afterload. These drugs also have an anti-arrhythmic effect by shortening the action potential through opening of the $\mathrm{K}^{+}$channel, and myocardial protective functions such as reducing the resistance of micro-coronary artery flow through relaxation of the smooth muscles of the blood vessels, and preconditioning.-8 Ischemic preconditioning, which is understood to reduce the size of the infarct by protecting the myocardium from severe ischemia following one or more episodes of myocardial ischemia-reperfusion, is known to occur as the $\mathrm{K}^{+}$channel is opened. Nicorandil has a function similar to ischemic preconditioning and is known to reduce the size of the infarct and promote the recovery of systolic function after infarction ${ }^{26-30}$

The Impact of Nicorandil in Angina research, which was a large-scale study of the myocardial protective effect of nicorandil in the high-risk group of patients with stable angina, reported that $13.1 \%$ of patients who had oral nicorandil died from coronary artery disease or were admitted unexpectedly for non-fatal myocardial infarction or chest pains, which was significantly lower than the $15.5 \%$ of patients who given placebo, so nicorandil could improve prognosis in stable angina? In one study of patients with UAP, Patel et al reported that the frequencies of transient myocardial ischemia, ventricular tachycardia and supraventricular tachycardia were reduced in patients who had oral nicorandil1. ${ }^{10}$ Another study of patients with myocardial infarction who had PCI reported that those who had an injection of nicorandil showed significant improvement in

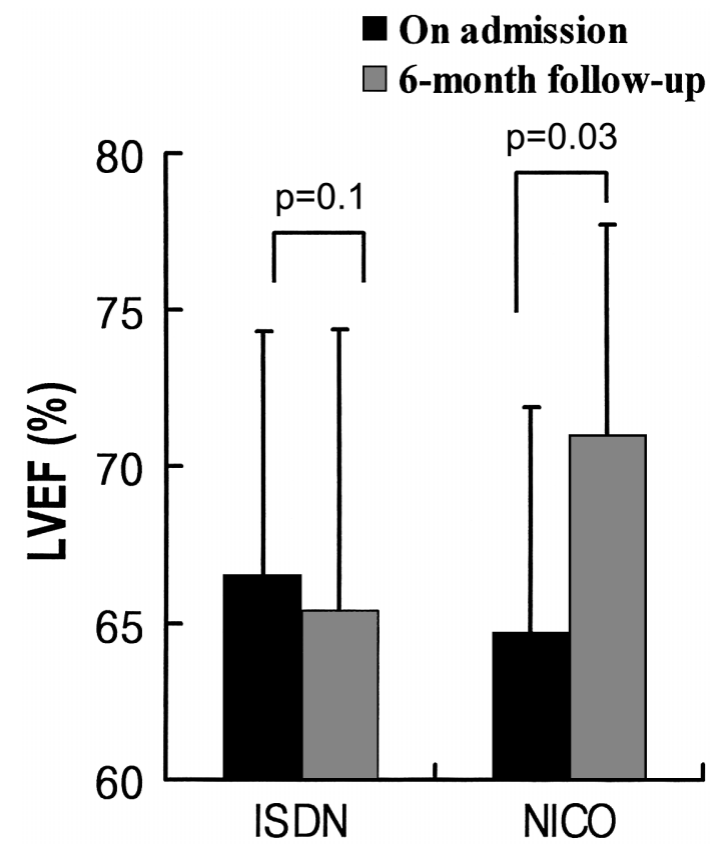

Fig 2. Comparative left ventricular ejection fraction (LVEF) measured by echocardiography on admission and at 6 months followup in the isosorbide dinitrate (ISDN) and nicorandil (NICO) infusion groups.

LV function, wall motion score index and regional wall motion, as well as less frequent complications in hospital and less frequent no-reflow phenomenon on contrast echocardiography!1,31-33 Investigations of the myocardial protective effect of nicorandil during PCI reported that STsegment sum and QT dispersion during PCI decreased in chronic stable angina patients after oral nicorandil was administered for 1 week! ${ }^{2,34}$ Ikeda et al compared the degree of ST-segment elevation in acute myocardial infarction patients who required primary coronary artery intervention in those injected with nicorandil and those with isosorbide dinitrate 35

The present study investigated UAP patients treated with nicorandil for $12-48 \mathrm{~h}$ prior to $\mathrm{PCI}$, and examined the myocardial protective effect of nicorandil based on the rate of increase of myocardial troponin. The low rate of increase in such patients suggests a myocardial protective effect, which can be explained by nicorandil inhibiting myocardial damage during PCI. The effect is considered to originate from ischemic preconditioning, but long-term large-scale research on how such a transient myocardial protective effect influences long-term prognosis is needed.

\section{Study Limitation}

The present study has a potential limitation because we investigated the myocardial protective effects of nicorandil prospectively and although the treatment regimen was allocated randomly, it was open labeled.

\section{References}

1. Klein LW, Kramer BL, Howard E, Lesch M. Incidence and clinical significance of transient creatine kinase elevations and the diagnosis of non Q-wave myocardial infarction associated with coronary angioplasty. J Am Coll Cardiol 1991; 17: 621-626.

2. Oh JK, Shub C, Ilstrup DM, Reeder GS. Creatine kinase release after successful percutaneous transluminal coronary angioplasty. Am 
Heart J 1985; 109: 1225-1231.

3. Pauletto P, Piccolo D, Scannapieco G, Vescovo G, Zaninotto M, Corbara F, et al. Changes in myoglobin, creatine kinase and creatine kinase-MB after percutaneous transluminal coronary angioplasty for stable angina pectoris. Am J Cardiol 1987; 59: 999-1000.

4. Kim JH, Jeong MH, Sim DS, Lee SH, Hong YJ, Park OY, et al. The Usefulness of cardiac troponin as a marker detecting minor myocardial injury after percutaneous coronary intervention. Korean Circulation J 2002; 32: 413-419.

5. Akai K, Wang Y, Sato K. Vasodilatory effect of nicorandil on coronary arterial microvessels: Its dependency on vessel size and the involvement of the ATP-sensitive potassium channels. J Cardiovasc Pharmacol 1995; 26: $541-547$.

6. Auchampach JA, Cavero I, Gross GJ. Nicorandil attenuates myocardial dysfunction associated with transient ischemia by opening ATPdependent potassium channels. J Cardiovasc Pharmacol 1992; 20: $765-771$.

7. Mizunuma T, Nithipatikom K, Gross GJ. Effects of nicorandil and glyceryl trinitrate on infarct size, adenosine release, and neutrophil infiltration in the dog. Cardiovasc Res 1995; 29: 482-489.

8. Dairaku Y, Miura T, Harada N, Kimura M, Okamura T, Iwamoto H, et al. Effect of ischemic preconditioning and mitochondrial KATP channel openers on chronic left ventricular remodeling in the ischemic-reperfused rat heart. Circ J 2002; 66: 411-415.

9. The IONA Study group. Effect of nicorandil on coronary events in patients with stable angina: The Impact Of Nicorandil in Angina (IONA) randomised trial. Lancet 2002; 359: 1269-1275.

10. Patel DJ, Purcell HJ, Fox KM. Cardioprotection by opening of the $\mathrm{K}(\mathrm{ATP})$ channel in unstable angina. Is this a clinical manifestation of myocardial preconditioning? Results of a randomized study with nicorandil: CESAR 2 investigation: Clinical European studies in angina and revascularization. Eur Heart J 1999; 20: 51 - 57 .

11. Ito H, Taniyama Y, Iwakura K, Nishikawa N, Masuyama T, Kuzuya $\mathrm{T}$, et al. Intravenous nicorandil can preserve microvascular integrity and myocardial viability in patients with reperfused anterior wall myocardial infarction. J Am Coll Cardiol 1999; 33: 654-660.

12. Kato T, Kamiyama T, Maruyama Y, Tanaka S, Yoshimoto N. Nicorandil, a potent cardioprotective agent, reduces QT dispersion during coronary angioplasty. Am Heart J 2001; 141: 940-943.

13. Ryan TJ, Faxon DP, Gunnar RM, Kennedy JW, King SB 3rd, Loop $\mathrm{FD}$, et al. Guidelines for percutaneous transluminal coronary angioplasty. A report of the American College of Cardiology/American Heart Association task force on assessment of diagnostic and therapeutic cardiovascular procedures. Circulation 1988; 78: 486-502.

14. Sheehan FH, Braunwald E, Canner P, Dodge HT, Gore J, Van Natta $P$, et al. The effect of intravenous thrombolytic therapy on left ventricular function: A report on tissue-type plasminogen activator and streptokinase from the Thrombolysis in Myocardial Infarction (TIMI Phase I) trial. Circulation 1987; 75: 817-829.

15. Karim MA, Shinn M, Oskarsson H, Windle J, Deligonul U. Significance of cardiac troponin $\mathrm{T}$ release after percutaneous transluminal coronary angioplasty. Am J Cardiol 1995; 76: 521-523.

16. Hunt AC, Chow SL, Shiu MF, Chilton DC, Cummins B, Cummins $\mathrm{P}$. Release of creatine kinase-MB and cardiac specific troponin I following percutaneous transluminal coronary angioplasty. Eur Heart $J$ 1991; 12: 690-694.

17. Ravkilde J, Nissen H, Mickley H, Andersen PE, Thayssen P, Harder M. Cardiac troponin T and CK-MB mass release after visually successful percutaneous transluminal coronary angioplasty in stable angina pectoris. Am Heart J 1994; 127: 13-20.

18. Talasz H, Genser N, Mair J, Dworzak EA, Friedrich G, Moes N, et al. Side-branch occlusion during percutaneous transluminal coronary angioplasty. Lancet 1992; 339: 1380-1382.

19. Katus HA, Remppis A, Neumann FJ, Scheffold T, Diederich KW,
Vinar G, et al. Diagnostic efficiency of troponin T measurements in acute myocardial infarction. Circulation 1991; 83: 902-912.

20. Rottbauer W, Greten T, Muller-Bardorff M, Remppis A, Zehelein J, Grunig E, Katus HA. Troponin T: A diagnostic marker for myocardial infarction and minor cardiac cell damage. Eur Heart J 1996; 17: F3-F8.

21. Antman EM, Tanasijevic MJ, Thompson B, Schactman M, McCabe $\mathrm{CH}$, Cannon $\mathrm{CP}$, et al. Cardiac-specific troponin I levels to predict the risk of mortality in patients with acute coronary syndromes. $N$ Engl J Med 1996; 335: 1342-1349.

22. Lee SH, Jeong MH, Park JS, Kim W, Kim KH, Kang KT, et al. The long-term clinical significance of troponin and electrocardiogram in patients with unstable angina. Korean J Med 2001; 61: 506-517.

23. Fuchs S, Kornowski R, Mehran R, Lansky AJ, Satler LF, Pichard $\mathrm{AD}$, et al. Prognostic value of cardiac troponin-I levels following catheter-based coronary interventions. Am J Cardiol 2000; 85: $1077-1082$.

24. Nageh T, Sherwood RA, Harris BM, Thomas MR. Cardiac troponin I for risk stratification following percutaneous coronary artery intervention in acute coronary syndromes. Catheter Cardiovasc Interv 2002; 55: 37-42.

25. Cantor WJ, Newby LK, Christenson RH, Tuttle RH, Hasselblad V, Armstrong PW, et al. Prognostic significance of elevated troponin I after percutaneous coronary intervention. J Am Coll Cardiol 2002; 39: $1738-1744$

26. Murry CE, Jennings RB, Reimer KA. Preconditioning with ischemia: A delay of lethal cell injury in ischemic myocardium. Circulation 1986; 74: 1124-1136.

27. Mizumura T, Nithipatikom K, Gross GJ. Bimakalim, an ATP-sensitive potassium channel opener, mimics the effect of ischemic preconditioning to reduce infarct size, adenosine release, and neutrophil function in dogs. Circulation 1995; 92: 1236-1245.

28. Yellon DF, Alkuraifi AM, Pugsley WB. Preconditioning the human myocardium. Lancet 1993; 342: 276-277.

29. Matsubara T, Minatoguchi S, Matsuo H, Hayakawa K, Segawa T, Matsuno Y, et al. Three minutes, but not one minutes, ischemia and nicorandil have a preconditioning effect in patients with coronary artery disease. J Am Coll Cardiol 2000; 35: 345-351.

30. Sakai K, Yamagata T, Teragawa H, Matsuura H, Chayama K. Nicorandil enhances myocardial tolerance to ischemia without progressive collateral recruitment during coronary angioplasty. Circ J 2002; 66: $317-322$.

31. Tsubokawa A, Ueda K, Sakamoto H, Iwase T, Tamaki S. Effect of intracoronary nicorandil administration on preventing no-reflow/slow flow phenomenon during rotational atherectomy. Circ J 2002; 66: $1119-1123$.

32. Sugimoto K, Ito H, Iwakura K, Ikushima M, Kato A, Kimura R, et al. Intravenous nicorandil in conjunction with coronary reperfusion therapy is associated with better clinical and functional outcomes in patients with acute myocardial infarction. Circ J 2003; 67: 295-300.

33. Mizuo N, Iwao I, Yoshiya M, Yoshiaki S, Susumu N, Nehiro K, et al. Comparison between nicorandil and magnesium as an adjunct cardioprotective agent to percutaneous coronary intervention in acute anterior myocardial infarction. Circ J 2004; 68: 192-197.

34. Ueda H, Nakayama Y, Tsumura K, Yoshimaru K, Hayashi T, Yoshikawa J. Intravenous nicorandil can reduce the occurrence of ventricular fibrillation and QT dispersion in patients with successful coronary angioplasty in acute myocardial infarction. Can J Cardiol 2004; 20: 625-629.

35. Ikeda N, Yasu T, Kubo N, Hashimoto S, Tsuruya Y, Fujii M, et al. Nicorandil versus isosorbide dinitrate as adjunctive treatment to direct balloon angioplasty in acute myocardial infarction. Heart 2004; 90: $181-185$. 